\title{
Effect of Different Sowing Methods, Herbicides and Rhizobium Culture on Yield and Economics of Lentil (Lens culinaris L.)
}

\author{
P.K. Singh ${ }^{1 *}$, Chanchal Singh ${ }^{1}$, Pradeep Prasad ${ }^{2}$, Rajiv Nayan $^{3}$ and Kartikey Singh $^{4}$ \\ ${ }^{1}$ Krishi Vigyan Kendra, Jamui (Bihar), India \\ ${ }^{2}$ Department of Agronomy, SHUATS, Allahabad (U.P.), India \\ ${ }^{3}$ Department of Extension, SHUATS, Allahabad (UP), India \\ ${ }^{4}$ Krishi Vigyan Kendra, Burhanpur (M.P.), India \\ *Corresponding author
}

\section{Keywords \\ Establishment method, Pendimethalin, Rhizobium culture, Zero tillage \\ Article Info \\ Accepted: \\ 20 January 2018 \\ Available Online: \\ 10 February 2018}

\section{A B S T R A C T}

A field experiment was conducted during the winter season of 2013-14 and 2014-15 at Sijhauri village of Jamui district (Bihar) in farmers participatory mode to study the effect of different sowing methods, herbicides and rhizobium culture on yield and economics of lentil (Lens culinaris L.). The experiment was laid out in randomized block design comprising of eight treatment replicated thrice. The treatment were as $\mathrm{T}_{1}-$ Zero tillage, $\mathrm{T}_{2}$ - Conventional tillage, $\mathrm{T}_{3}-\mathrm{ZT}+$ Pendimethalin @ $1.00 \mathrm{~kg}$ ai ha-1, $\mathrm{T}_{4}$ - Zero tillage + pendimethalin at $1.00 \mathrm{~kg}$ as pre-emergence + Seed inoculation through Rhizobium culture $\mathrm{T}_{5^{-}}$Zero tillage + seed inoculation through Rhizobium culture, $\mathrm{T}_{6^{-}}$Conventional tillage + Pendimethalin at $1.00 \mathrm{~kg}$ ai $\mathrm{ha}^{-1}$ as pre-emergence, $\mathrm{T}_{7^{-}}$Conventional tillage + Pendimethalin at $1.00 \mathrm{~kg}$ ai ha ${ }^{-1}$ as pre-emergence + Seed inoculation through Rhizobium culture and $\mathrm{T}_{8}-$ Conventional tillage + Seed inoculation through Rhizobium culture. Zero tillage method of sowing recorded minimum weed population, minimum weeds dry weight $(22.3 \mathrm{~g})$ and maximum weed control efficiency $(28.98 \%)$ which was significantly superior to that recorded under conventional tillage. The results also revealed that treatment $\mathrm{T}_{4}$ was the best treatment with regard to weed control, growth parameters and yield attributes and yield. Zero tillage method of sowing recorded significantly higher values of all the growth parameters viz. plant height $(42 \mathrm{~cm})$, no. of branches plant ${ }^{-1}(5.30)$, no. of pods plant ${ }^{-1}(34)$, no. of seeds $\operatorname{pod}^{-1}(1.85)$ and test wt. $(24.50 \mathrm{~g})$ above conventional tillage and among the treatment combinations treatment $\mathrm{T}_{4^{-}}$Zero tillage + pendimethalin at $1.00 \mathrm{~kg}$ as preemergence +Seed inoculation through Rhizobium culture recorded highest growth parameters and grain yield $\left(10.94 \mathrm{q} \mathrm{ha}^{-1}\right)$. The maximum net return was obtained with treatment T4 (Rs. 36,280) and B: C ratio of 1.70.

\section{Introduction}

Lentil (Lens culinaris L.) is one of the oldest known crop. People in the Near East produced them for the first time more than 8000 years ago. Like most legumes, lentils have high nutritious value, consisting of about 25\% protein, $60 \%$ carbohydrate and $1 \%$ fat. Particularly, they are a good source of essential amino acids, such as lysine and arginine. Furthermore, lentil contains dietary fiber, iron, folate, magnesium and zinc (Ruiz 
et al., 1996, Popelka et al., 2004). Lentils are a rich, inexpensive source of protein, both for human and animal nutrition, which can complement cereal protein for several essential amino acids. Besides these lentils also contain saponins, high levels of saponins reduce micronutrient bioavailability, but beneficial effects also have been reported (Thompson, 1993).

Lentil is an important winter pulse crop in India. It is hardy and capable of withstanding extremes of weather and soil condition. However, due to its short stature, slow initial growth and long duration, its productivity is adversely affected by the presence of weeds.

The prominent weed species infesting lentil crop are Cynadon dactylon, Chenopodium album, Euphoriba hirta, Melilotus alba, Anagalis arvensis and Xanthium strumarium. The concept that high input in high yield also means is high risk, if weeds are not controlled. A weed free crop environment is therefore important both for increasing yield and income for the security of crop. There are number of factors for low production and productivity of lentil out of which weeds, being serious negative factors in crop production are responsible for reduction in the yield of lentil to a tune of $84 \%$ (Mohamed et al., 1997). Loss in seed yield may go to the extent of $45-65 \%$ under un-weeded condition.

During winter season, broad-leaved weeds may become dominant in the early stages of crop growth because of their fast growing nature and deep root system. Yasin et al., (1995) evaluated different herbicides for weed control in chickpea and lentil. Application of pendimethalin as pre-emergence herbicide proved better for control of weeds and high yield. According to Ahmad et al., (1996) preemergence application of Stomp 33 EC @ 1.25 and $1.50 \mathrm{~kg}$ ai/ha and hand weeding were equally effective in reducing dry weight of weeds than Treflan-48 EC. Pre-sowing seed inoculation with bio-fertilizer is a simple and cheap method for increasing pulse production under limited soil moisture. Pre-sowing seed treatment enhances germination, improves vigour, growth of root system, increases drought tolerance which helps in higher nutrient uptake leading to higher economics yield under limited soil moisture. Vermeiren et al., 1999 reported that several bacteria that are associated with the roots of crop plants can induce beneficial effects on their hosts often are collectively referred to as PGPR (Plant Growth Promoting Rhizobacteria).The biological fixation of nitrogen produced by these organisms can constitute significant and ecological favorable contribution soil fertility (Vlassak et al., 1992).

Zero tillage method of sowing in India, evoled about 15 years ago (Malik et al., 2002). Cereal System Initiative for South Asia (CSISA) has been promoting various resource conservation technologies (RCTs) for tillage and crop establishment of rice, wheat and pulse in ricewheat system. RCTs include Zero tillage, furrow irrigated raised bed system (FIRBS), laser land leveling, crop residue management, improved method of herbicide application and improved cultivars etc.

RCTs have been introduced in South Eastern part of Bihar to reduce the cost of cultivation, save precious resources like water, seed, fertilizer, energy, time, improve the quality of soil resource base for enhancing productivity. Zero tillage helps sowing of lentil at least 1215 days earlier at residual moisture.

Zero tillage seeding of lentil also allows band application of basal fertilizers which ensure placement of the phosphatic fertilizers right in the seed zone and also allows a saving of $25 \%$ in the seed rate to obtain sufficient plant stand as compared to traditional broadcasting. So, keeping these factors in mind, a study was 
conducted to understand the effect of different establishments, bio-fertilizer and weed control methods, yield and economics of lentil.

\section{Materials and Methods}

The field experiment was conducted at the Sijhauri village of Jamui district (Bihar) in farmers' participatory mode during the rabi season of 2013-14 and 2014-15. The site is geographically situated between $24^{0} 57.366 \mathrm{~N}$ latitude and $86^{\circ} 05.219 \mathrm{E}$ longitude. The experiment was laid out in factorial randomized block design with three replications. The experiment consisted of two tillage practices (zero tillage and conventional tillage) and herbicide (application and no application) along with Rhizobium inoculation and un-inoculation. Eight treatment combinations viz. $T_{1^{-}}$Zero tillage, $T_{2^{-}}$ Conventional tillage, $\mathrm{T}_{3^{-}}$Zero tillage + Pendimethalin at $1.00 \mathrm{~kg}$ as pre-emergence, $\mathrm{T}_{4}$ - Zero tillage + pendimethalin at $1.00 \mathrm{~kg}$ as pre-emergence +Seed inoculation through Rhizobium culture $\mathrm{T}_{5^{-}}$Zero tillage + seed inoculation through Rhizobium culture, $\mathrm{T}_{6^{-}}$ Conventional tillage + Pendimethalin at 1.00 $\mathrm{kg}$ ai $\mathrm{ha}^{-1}$ as pre-emergence, $\mathrm{T}_{7-}$ Conventional tillage + Pendimethalin at $1.00 \mathrm{~kg}$ ai ha ${ }^{-1}$ as pre-emergence + Seed inoculation through Rhizobium culture and $\mathrm{T}_{8}-$ Conventional tillage + Seed inoculation through Rhizobium culture were formulated. In zero tillage method the crop was sown through ZT seed drill without any tillage practice at $25 \mathrm{~cm}$ row spacing using seed rate $45 \mathrm{~kg} \mathrm{ha}^{-1}$ along with pre-plant herbicide glyphosate at $1.00 \mathrm{~kg}$ ai $\mathrm{ha}^{-1}$ before one week of sowing. Sowing of seed was done on $5^{\text {th }}$ November and $6^{\text {th }}$ November in 2013 and 2014 respectively. Whereas, in conventional method the field was ploughed three times and planking was done after each ploughing and then seeds were broadcasted in the field. Pre-emergence herbicide Pendimethalin at $1.00 \mathrm{~kg}$ ai ha ${ }^{-1}$ was applied two days after sowing. The total rainfall recorded during crop period was 18.5 and $22.2 \mathrm{~mm}$. The minimum temperature ranged from $5^{\circ} \mathrm{C}$ to $14^{\circ} \mathrm{C}$ and $5.5^{\circ} \mathrm{C}$ to $14^{\circ} \mathrm{C}$ and maximum temperature recorded ranged between $27^{\circ} \mathrm{C}$ to $37.5^{\circ} \mathrm{C}$ and $27^{\circ} \mathrm{C}$ to $38^{\circ} \mathrm{C}$ during 2013-14 and 2014-15 respectively. Mechanical and chemical analysis of soil was done before experiment to know the initial status of the soil. The soil of the field under study was sandy - loam with $\mathrm{pH} 6.9$, high in organic carbon $(0.75 \%)$, medium in available Nitrogen $\left(282.5 \mathrm{~kg} \mathrm{ha}^{-1}\right)$ medium in available Phosphorus $\left(22.43 \% \mathrm{~kg} \mathrm{ha}^{-1}\right.$ ) and potassium $\left(185 \mathrm{~kg} \mathrm{ha}^{-1}\right)$. Lentil variety DPL-62 was used as test crop. Recommended dose of N $(20 \mathrm{~kg}$ $\mathrm{ha}^{-1}$ ) and $\mathrm{P}\left(45 \mathrm{~kg} \mathrm{ha}^{-1}\right)$ were applied through DAP at the sowing time. Herbicide (Pendimethalin) was applied after 48 hours of seeding with manual operated knapsack sprayer fitted with flat fan nozzle using 500 litre of water $\mathrm{ha}^{-1}$. The weeds were collected from an area of $1 \mathrm{~m}^{2}$ size quadrate at 30 days of sowing and categorized in three groups viz. broad leaf weeds, grasses and sedges and their respective number was counted. These samples were first sun dried and then dried in an electric oven at $70^{\circ} \mathrm{C}$ for 72 hours and there dry weight was recorded. Crop was harvested manually in third week of March in both the years of experiments. Data on growth, yield attributes and yield were recorded after harvest whereas weeds data was recorded at 30 DAS as per normal procedure. The grain yield data was reported at $14 \%$ grain moisture.

\section{Results and Discussion}

Density of weeds, weed dry weight and weed control efficiency were significantly influenced by the establishment method, application of herbicide and inoculation of rhizobium culture. However individually of the density of broad leaf weeds, grasses and sedges also showed significantly variation among tillage practices. herbicides and rhizobium culture. 
Table.1 Effect of sowing methods, herbicide and Rhizobium culture on weed density, weed dry weight and weed control efficiency in lentil (pooled data over two years)

\begin{tabular}{|c|c|c|c|c|c|c|}
\hline \multirow{2}{*}{\multicolumn{2}{|c|}{ Treatments }} & \multicolumn{3}{|c|}{ Weeds density (No. m- ${ }^{2}$ ) } & \multirow{2}{*}{$\begin{array}{l}\text { Weeds dry } \\
\text { weight } \\
\left(\mathrm{g} / 0.25 \mathrm{~m}^{2}\right)\end{array}$} & \multirow{2}{*}{$\begin{array}{c}\text { Weed } \\
\text { control } \\
\text { efficiency } \\
(\%)\end{array}$} \\
\hline & & $\begin{array}{l}\text { Broad leaf } \\
\text { weeds }\end{array}$ & Grasses & Sedges & & \\
\hline \multicolumn{7}{|c|}{ Tillage Practices } \\
\hline $\mathbf{T}_{1}$ & Zero tillage (ZT) & 14 & 3 & 2 & 22.3 & 28.98 \\
\hline $\mathbf{T}_{2}$ & Conventional Tillage (CT) & 22 & 14 & 6 & 30.2 & 3.8 \\
\hline \multicolumn{2}{|c|}{ F-test } & $S$ & $S$ & S & $S$ & $S$ \\
\hline \multicolumn{2}{|c|}{ S.Ed. $(\square)$} & 0.35 & 0.22 & 0.17 & 0.20 & 0.12 \\
\hline \multicolumn{2}{|c|}{$\mathrm{CD}(\mathrm{P}=\mathbf{0 . 0 5})$} & 1.14 & 0.70 & 0.56 & 0.65 & 0.40 \\
\hline \multicolumn{7}{|c|}{ Treatment Combination } \\
\hline $\mathbf{T}_{3}$ & $\mathrm{ZT}+$ Pendimethalin & 20 & 12 & 5 & 31.4 & 42.50 \\
\hline $\mathbf{T}_{4}$ & $\begin{array}{l}\mathrm{ZT}+\text { pendimethalin }+ \text { Seed } \\
\text { inoculation }\end{array}$ & 12 & 4 & 2 & 12.5 & 60.19 \\
\hline $\mathbf{T}_{5}$ & $\mathrm{ZT}+$ Seed inoculation & 14 & 3 & 2 & 24.2 & 22.92 \\
\hline $\mathrm{T}_{6}$ & $\mathrm{CT}+$ pendimethalin & 18 & 5 & 4 & 19.41 & 40.74 \\
\hline $\mathbf{T}_{7}$ & $\begin{array}{l}\mathrm{CT}+\text { pendimethalin }+ \text { Seed } \\
\text { inoculation }\end{array}$ & 14 & 4 & 4 & 15.81 & 53.36 \\
\hline $\mathbf{T}_{8}$ & $\mathrm{CT}+$ Seed Inoculation & 15 & 5 & 3 & 18.34 & 17.43 \\
\hline \multicolumn{2}{|c|}{ F-test } & $S$ & $S$ & $S$ & $S$ & $S$ \\
\hline \multicolumn{2}{|c|}{ S.Ed. (+) } & 0.35 & 0.30 & 0.17 & 0.22 & 0.13 \\
\hline \multicolumn{2}{|c|}{$\mathrm{CD}(\mathrm{P}=0.05)$} & 1.15 & 0.73 & 0.54 & 0.69 & 0.39 \\
\hline \multicolumn{7}{|c|}{ Interaction } \\
\hline \multicolumn{2}{|c|}{ F-test } & $S$ & $S$ & $S$ & $S$ & S \\
\hline \multicolumn{2}{|c|}{ S.Ed(.+) } & 0.71 & 0.45 & 0.35 & 0.88 & 0.28 \\
\hline \multicolumn{2}{|c|}{$\mathrm{CD}(\mathrm{P}=0.05)$} & 2.31 & 1.47 & 1.12 & 2.83 & 0.91 \\
\hline
\end{tabular}


Table.2 Effect of different sowing methods, herbicides and rhizobium culture on yield attributes of lentil (Lens culinaris L.)

\begin{tabular}{|c|c|}
\hline \multicolumn{2}{|c|}{ Treatments } \\
\hline \multicolumn{2}{|c|}{ Tillage Practices } \\
\hline $\mathbf{T}_{1}$ & Zero tillage (ZT) \\
\hline $\mathbf{T}_{2}$ & Conventional Tillage (CT) \\
\hline \multicolumn{2}{|c|}{ F-test } \\
\hline \multicolumn{2}{|c|}{ S.Ed. (+) } \\
\hline \multicolumn{2}{|c|}{$\mathrm{CD}(\mathrm{P}=0.05)$} \\
\hline \multicolumn{2}{|c|}{ Treatment combination } \\
\hline $\mathbf{T}_{3}$ & ZT+ Pendimethalin \\
\hline $\mathbf{T}_{4}$ & $\begin{array}{l}\text { ZT+Pendimethalin+Seed } \\
\text { inoculation }\end{array}$ \\
\hline $\mathbf{T}_{5}$ & $\mathrm{ZT}+$ Seed inoculation \\
\hline$T_{6}$ & $\mathrm{CT}+$ Pendimethalin \\
\hline $\mathbf{T}_{7}$ & $\begin{array}{l}\mathrm{CT}+\text { Pendimethalin+Seed } \\
\text { inoculation }\end{array}$ \\
\hline $\mathbf{T}_{8}$ & $\mathrm{CT}+$ Seed inoculation \\
\hline \multicolumn{2}{|c|}{ F-test } \\
\hline \multicolumn{2}{|c|}{ S.Ed. (+) } \\
\hline \multicolumn{2}{|c|}{$\mathrm{CD}(\mathrm{P}=0.05)$} \\
\hline \multicolumn{2}{|c|}{ Interaction } \\
\hline \multicolumn{2}{|c|}{ F-test } \\
\hline \multicolumn{2}{|c|}{ S.Ed(+) } \\
\hline CD & $=0.05)$ \\
\hline
\end{tabular}

\begin{tabular}{|c|c|c|c|c|}
\hline $\begin{array}{l}\text { Plant height } \\
(\mathrm{cm})\end{array}$ & $\begin{array}{c}\text { Branches plant } \\
\text { (no.) }\end{array}$ & $\begin{array}{c}\text { Pods plant }^{-1} \\
\text { (no.) }\end{array}$ & $\begin{array}{l}\text { Seed pod } \\
\text { (no.) }\end{array}$ & $\begin{array}{l}\text { Test weight } \\
\text { (g) }\end{array}$ \\
\hline 42.0 & 5.30 & 34.00 & 1.85 & 24.50 \\
\hline 31.7 & 3.00 & 25.00 & 1.60 & 21.30 \\
\hline$S$ & $S$ & $S$ & $S$ & $S$ \\
\hline 0.35 & 0.16 & 0.34 & 0.15 & 0.34 \\
\hline 1.14 & 0.50 & 1.09 & 0.05 & 1.20 \\
\hline 34.8 & 3.88 & 26.70 & 1.68 & 22.40 \\
\hline 38.6 & 4.48 & 30.70 & 1.82 & 23.60 \\
\hline 40.2 & 4,92 & 32.80 & 1.89 & 24.00 \\
\hline 27.7 & 2.56 & 23.00 & 1.42 & $21 / 00$ \\
\hline 32.4 & 3.98 & 26.50 & 1.58 & 23.30 \\
\hline 30.5 & 3.75 & 25.60 & 1.52 & 22.00 \\
\hline S & S & $S$ & $S$ & $S$ \\
\hline 0.32 & 0.16 & 0.34 & 0.12 & 0.34 \\
\hline 1.04 & 0.52 & 1.10 & 0.06 & 1.23 \\
\hline S & S & S & S & S \\
\hline 0.87 & 0.34 & 0.72 & 0.03 & 0.77 \\
\hline 2.83 & 1.11 & 2.35 & 010 & 2.46 \\
\hline
\end{tabular}

Table.3 Effect of different sowing methods, herbicides and rhizobium culture on yield and economics of lentil (Lens culinaris L.)

\begin{tabular}{|c|c|}
\hline \multicolumn{2}{|c|}{ Treatments } \\
\hline \multicolumn{2}{|c|}{ Tillage Practices } \\
\hline $\mathbf{T}_{1}$ & Zero tillage (ZT) \\
\hline $\mathbf{T}_{2}$ & Conventional Tillage (CT) \\
\hline \multicolumn{2}{|c|}{ F-test } \\
\hline \multicolumn{2}{|c|}{ S.Ed. $(+)$} \\
\hline \multicolumn{2}{|c|}{$\mathrm{CD}(\mathrm{P}=0.05)$} \\
\hline \multicolumn{2}{|c|}{ Treatment combination } \\
\hline$T_{3}$ & ZT + Pendimethalin \\
\hline $\mathbf{T}_{4}$ & $\begin{array}{l}\text { ZT+Pendimethalin }+ \text { Seed } \\
\text { inoculation }\end{array}$ \\
\hline $\mathbf{T}_{5}$ & ZT+Seed inoculation \\
\hline $\mathrm{T}_{6}$ & $\mathrm{CT}+$ Pendimethalin \\
\hline $\mathbf{T}_{7}$ & $\begin{array}{l}\text { CT+Pendimethalin+Seed } \\
\text { inoculation }\end{array}$ \\
\hline $\mathbf{T}_{8}$ & $\mathrm{CT}+$ Seed inoculation \\
\hline \multicolumn{2}{|c|}{ F-test } \\
\hline \multicolumn{2}{|c|}{ S.Ed. $(+)$} \\
\hline \multicolumn{2}{|c|}{$\mathrm{CD}(\mathrm{P}=0.05)$} \\
\hline \multicolumn{2}{|c|}{ Interaction } \\
\hline \multicolumn{2}{|c|}{ F-test } \\
\hline \multicolumn{2}{|c|}{ S.Ed. (+) } \\
\hline CD & $=0.05)$ \\
\hline
\end{tabular}

\begin{tabular}{|c|c|c|c|c|c|}
\hline $\begin{array}{l}\text { Grain yield } \\
\left(\mathbf{q} \cdot \mathrm{ha}^{1}\right)\end{array}$ & $\begin{array}{l}\text { Stover yield } \\
\left(\mathbf{q} \text { ha- }^{-1}\right)\end{array}$ & $\begin{array}{l}\text { Cost of cultivation } \\
\text { (Rs. ha- }{ }^{1} \text { ) }\end{array}$ & $\begin{array}{l}\text { Gross } \\
\text { return } \\
\text { (Rs. ha- }{ }^{1} \text { ) }\end{array}$ & $\begin{array}{l}\text { Net return } \\
\left(\text { Rs. ha }{ }^{-1}\right)\end{array}$ & $\begin{array}{l}\mathrm{B}: \mathrm{C} \\
\text { ratio }\end{array}$ \\
\hline 10.6 & 20.42 & 20950 & 63600 & 42650 & 2.0 \\
\hline 7.6 & 12.62 & 23150 & 45600 & 22450 & 0.97 \\
\hline $\mathrm{S}$ & $S$ & & & & \\
\hline 0.20 & 0.15 & & & & \\
\hline 0.66 & 0.49 & & & & \\
\hline & & & & & \\
\hline 10.88 & 21.00 & 20900 & 48000 & 27100 & 1.30 \\
\hline 10.94 & 21.24 & 21800 & 58080 & 36280 & 1.70 \\
\hline 10.72 & 20.32 & 21600 & 57300 & 35100 & 1.60 \\
\hline 7.85 & 12.80 & 21900 & 46000 & 24100 & 1.10 \\
\hline 8.00 & 13.15 & 22200 & 46700 & 25400 & 1.14 \\
\hline 7.93 & & 21500 & 45300 & 23800 & 1.10 \\
\hline$S$ & $S$ & & & & \\
\hline 0.18 & 0.16 & & & & \\
\hline 0.60 & 0.52 & & & & \\
\hline$S$ & $S$ & & & & \\
\hline 0.41 & 0.32 & & & & \\
\hline 1.33 & 1.05 & & & & \\
\hline
\end{tabular}


The data collected further revealed that minimum weed population 14, 3 and 2 as broad leaf, grasses and sedges respectively was recorded in zero tillage and hence lower weed dry weight and maximum weed control efficiency (28.98\%) was recorded by zero tillage method of sowing and was nine times more than that recorded in conventional tillage (3.8\%). Similar findings were also reported by Battikhi and Suleiman (1999).

In zero tillage lentil plots, lesser weed infestation was observed due to minimal soil disturbance which did not allow the weed seeds to come to the surface and emerge. The other reason for this might be due to better placement of seed and fertilizer and at right depth which resulted in early germination, vigorous growth of lentil than weeds resulting in lower weed density and weed dry weight.

The minimal soil disturbance under no-till ensures that most weed seeds are left under the soil surface and do not emerge as a major production constraint. Generally, the weed flora observed in lentil is complex including grassy, broadleaf and some sedges. Similar result was reported by Gossen and Derksen (2003).

Pre-emergence of herbicide Pendimethalin @ $1.00 \mathrm{~kg}$ ai ha ${ }^{-1}$ was found more effective in reducing dry weight of weeds. Lower weed density and weed dry weight in Pendimethalin treated plots was due to better control of weeds by this herbicide Chaudhary et al., (2011). However' Rhizobium inoculation increased both root and vegetative growth resulting in increase in biomass production. Interaction effect of biofertilizer, tillage practices and weed control methods was unchanged with weed density and weed dry weight. However, weed control efficiency was significantly affected by biofertilizer, tillage practices and weed control methods which was recorded as $42.50 \%$ in treatment $\mathrm{T}_{3}(\mathrm{ZT}+$ Pendimethalin) and $60.19 \%$ in treatment $\mathrm{T}_{4}$ (Zero tillage + pendimethalin at $1.00 \mathrm{~kg}$ as pre-emergence +Seed inoculation through Rhizobium culture).

\section{Effect on yield}

Zero tillage method of sowing proved significantly superior with regards to growth attributes and yield. All the growth parameters showed significant variation by Zero tillage and application of pendimethalin along with inoculation of Rhizobium culture. Similar finding was also reported by Gossen and Derksen (2003) Chandrakar et al., (2016). Zero tillage method of sowing, application of pendimethalin and inoculation of rhizobium culture resulted in highest plant height $(32.4 \mathrm{~cm})$, maximum no. of branches per plant (3.98), maximum no. of pods per plant (26.5), maximum no. of seeds per plant (1.58) and highest test weight $(23.30 \mathrm{~g})$ this might be due to better establishment of crop plant as the result of less weed competition under zero tillage. Less weed competition provides more sun light, better aeration and also provides better nutrient availability. Rhizobium inoculation helps survival of rhizobium cells/nodules. Rhizobium inoculation had significant influence and gave maximum number of pods plant ${ }^{-1}$, number of seed pod $^{-1}$, test weight, seed, stover yield and harvest index (Beyranyand et al., 2012). Sharma and Singh (2014) also reported that biofertilizer like Rhizobium culture significantly increased all yield attributes. This might be due to greater availability of nitrogen and phosphorus to plant.

\section{Economics}

A perusal of table reveals that highest net returns (Rs.36280) and benefit cost ratio 1.70) was recorded with Zero tillage method of sowing, application of pendimethalin and inoculation of rhizobium culture over rest of treatments. Excellent control of dominant weeds resulting in no adverse effect on crop growth resulted in higher yield and this might have caused superior economics indices in these treatments. Less net return and benefit cost ratio was recorded with conventional method and weedy check having poor weed control thus low crop yield (Mohamed et al., 1997 and Yasin et al., 1995). 


\section{References}

Ahmad, S.S, A, Abid, Z.A. Cheema and A. Tanveer 1996. Study of various Chemical weed control practices in lentil (Lens culinaris L. Medic) J. Agric. Res. 34 (23): 127-134.

Battikhi, A.M. and Suleiman, A.A. 1999. Effect of tillage system on soil strength and bulk Density of vertisols. J Agron Crop Sci 182:285-290.

Beyranv and, Maryam, Pezeshkpour, Payam and Nasrollahi. 2012. Study the effect of nitrogen, Phosphorus and bio-fertilizer vermicompost on yield and yield components of lentil in autumn and spring sowing in rainfed conditions of Khorrambad, Iran. Annals of Biology research 3(12): 5644-5646.

Chandarakar. D.K., Nagre, S.K., Ransing, D.M. and Singh, A.P. 2016. Influence of different Herbicides on growth, yield and economics of lentil. Indian Journal of Weed Science 48(2): 182-185

Chaudhary, S.U., Iqbal, J., Hussain, M. and Wajid, A., 2011. Economical weed control in Lentils Crop. The Journal of Animal \& Plant Sciences, 21(4): 734-737.

Malik, R.K, Yadav, A, Singh, S, Malik, R.S, Balyan, R.S, and Banga, R.S. 2002. Herbicide Resistance management and evalution of zero-tillage - a success story. CCSHAU, Reserch Bulletin, 200243

Mohamed, E.S., A.H. Nourali, G.E. Mohammad, M.I. Mohamed and M.C. Saxena 1997.Weed management in irrigated lentil in northern Sudan. Weed Res. 37(4): 211-218.

Popekla J. C., Terryn N. and Higgins T.J.V.
2004. Gene technology for grain legumes: can it contribute to the food challenge in developing countries. Plant Science 167: 195-206.

Ruiz R.G., Price K.R., Arthur A.E., Rose M.E., Rhodes M.J. and Fenwick R.G. 1996. Effect of soaking and cooking on the saponin content and composition of chickpeas (Cicer arietinium) and lentils (Lens culinaris). Journal of Agriculture and Food Chemistry 44: 1 526-30.

Sharma, Babita and Singh, Ravindra Swaroop. 2014. A study on the interactive effect of different fungicides with Rhizobium in lentil (Lenus culinaris). International Journal of Life Science Reserch. Vol. 2, Issue 3, pp 105-113.

Thompson L.U. 1993. Potential health benefits and problems associated with antiNutrients in foods. Food Reserch International 26: 131-49.

Vermeiren H, Willems A, Schoofs G, De Mot R, Keijers V, Hai W, Vanderleyden J. 1999. The rice inoculants strain Alcaligenes faecalis A 15 is nitrogenfixing Pseudomonas stutzeri. Systematic and Applied Microbiology 22, 215-224.

Vlassak K, Van Holm L, Duchateau L, Vanderleyden L, De Mot R. 1992. Isolation and characterization of fluorescent Pseudomonass associated with the roots of the rice and banana grown in Sri Lanka. Plant Soil 145, 5163.

Yasin, J.Z., S. AL. Thahabi, B.E. Abu. Irmaileh, M.C. Saxena and N.I. Haddad (1995). Chemical weed - control in Chickpea and Lentil. Intern J. Pest Manag. 41(1): 60-65.

\section{How to cite this article:}

Singh, P.K., Chanchal Singh, Pradeep Prasad, Rajiv Nayan and Kartikey Singh. 2018. Effect of Different Sowing Methods, Herbicides and Rhizobium Culture on Yield and Economics of Lentil (Lens culinaris L.). Int.J.Curr.Microbiol.App.Sci. 7(02): 2408-2414. doi: https://doi.org/10.20546/ijcmas.2018.702.293 